DOI: 10.2478/auseur-2019-0016

\title{
Hungarian Press in Bucharest and Osijek - Before the Peace Treaty of Trianon
}

\author{
A Review of the Volume \\ Béla, Makkai: Határon túli magyar sajtó - Trianon elôtt. \\ Bukaresti és eszéki magyar lapok az identitásốrzés és \\ kisebbségi érdekvédelem szolgálatában (1860-1918) \\ [Hungarian Journals/Newspapers from Bucharest and Osijek \\ in the Service of Identity Keeping and Protection of \\ Minority Interests (1860-1918)] $]^{1}$
}

\author{
Kinga-Tünde KOVÁCS \\ Bethlen Gábor College, Aiud \\ e-mail: kkingat92@gmail.com
}

The book of historian Béla Makkai, Associate Professor at Károli Gáspár Reformed University, was published in 2016 by the Nemzeti Média- és Hírközlési Hatóság - Médiatanács - Médiatudományi Intézet (National Media and Infocommunications Authority - Hungary - Institute for Media Studies). This work was the $23^{\text {rd }}$ publication in the book series entitled Médiatudományi Könyvtár (Library of Media Science) edited by András Koltay and Levente Nyakas.

The title and subtitle of the book, and even the exact timing of the study (and the explanations associated with it, which we can read in the preface) help to contextualize the content of the book, outline the expectations of the reader, and suggest to the interested reader that the book is written not only for a strictly limited audience, the 'professionals', but also for a wider readership. The 'crossborder' syntagm is also explained in the preface, because 'we have to look for the Hungarians and their press products mentioned in the title on the other side of the borders of that time'. 'However, between 1867 and 1918, almost all Hungarians (including the Szekler island of Bukovina) lived in the Austro-

1 Published by Médiatudományi Intézet, Budapest, 2016.

2 W. cit., p. 7.; in Hungarian: „,a címben említett magyarokat és sajtótermékeiket az akkori határok másik oldalán kell keresnünk". 
Hungarian Monarchy, the second largest empire in Europe'. ${ }^{3}$ However, the question may arise: if the beginning of the age of dualism is dated at 1867, what justifies the time interval studied by the author to be the period of 1860-1918? The year 1860 becomes a relevant reference point because the first Hungarianlanguage newspaper of the Romanian principality was launched in May 1860 under the leadership of Ádám Várhegyi. ${ }^{4}$

The author emphasizes that "the "cross-border" Hungarian press organs investigated by him were important means of modern communication, information, and political orientation for the Budapest Government'. ${ }^{5}$ The journals had a dual function: they proved to be important not only for the Hungarian Government but also as an important means of uniting the Hungarian community living here in the cultural sphere, preserving their identity, because "they could "shape" Hungarian culture and shape its prosperous craftsmen but also a large number of domestic servants and seasonal workers, isolated from their own language environment and community life, and, moreover, the Csángós, who were temporarily under the exclusive influence of Romanian linguistic policy'. ${ }^{6}$

The author also reveals the factors that complicate the research by making data collection process more difficult (e.g. the second half of the $19^{\text {th }}$ century is extremely poorly documented), ${ }^{7}$ thus proving that the work is a result of serious scientific work and can gain readers' trust from the beginning of the book.

The main text of the book consists of ten chapters with the following titles: 'The First' - The 'Bucharest Hungarian Bulletin' (1860), From the Romanian version to the Hungarian title - The 'Bucharest Gazette' ${ }^{8}$ (1876-1885), The Fighting - Threesome, 'The Voice of the People' - The 'Romanian Hungarian People's Journal' (1900), Changing Era - with State Aid - The 'Bucharest Hungarian Newspaper' (1901-1908), The Unwanted Guardian of Purity of Public Life - The 'Romanian Newspaper' (1907-1910), Safe in the Bottom - The 'Romanian Hungarian Newspaper' (1908-1916), A New Beginning - Beyond the Border, in the Homeland - The 'Slavonian Hungarian Newspaper' (1908-1918), In the Shadow of Weapons - The 'Bucharest Hungarian Newspaper' (1918), The Hungarian Cross-Border Press in the Dualist Period. A table of contents, preface,

3 Ibidem. In Hungarian: „1867 és 1918 között azonban még a magyarság csaknem egésze (beleértve a bukovinai székely népszigetet is) Európa második legnagyobb birodalmában, az OsztrákMagyar Monarchiában élt.”

4 W. cit., p. 11.

5 W. cit., p. 8. In Hungarian: “»határon túli« magyar orgánumok a modern kori kapcsolattartás, tájékoztatás és politikai orientálás fontos eszközét jelentették a budapesti kormányzat számára”.

6 Ibidem. In Hungarian: ,általuk a magyar kultúra »elérte« s némiképp formálni tudta nem csak a jómódú iparosságot, de a saját nyelvi közegétől és közösségi életétől elszigetelten múködő cselédek és idénymunkások sokaságát, mi több, átmenetileg a kizárólagos román nyelvi-politikai befolyásnak kitett csángókat is.”

7 Ibidem.

8 In Romanian: Gazeta de Bucuresci. 
bibliography, and epilogue are added to the main text. The epilogue comes from the pen of István Apró, in whose writing not only the book is evaluated, but also theories and practices of research are described (for example, on the question of interpretation of history). ${ }^{9}$

The chapters of the main text deal with the beginnings, functioning, objectives, and causes of the failure/disappearance of these journals/newspapers. Changes in historical-political-social life have also brought about changes in the press world. The final reference point of the period examined by the author is also determined by a historical event: the end of dualism, the disintegration of the Austro-Hungarian Monarchy. The last chapter seeks to summarize the history of press of the dualistic era. It states: 'The pages of the emigrated Hungarians in the neighbouring Romanian and Croatian (Serbian) linguistic areas were operating in an unfriendly and even hostile political environment. ${ }^{10}$ In order to survive, they have mediated between the two 'homelands' ${ }^{11}$ I believe that in such a situation the newspapers had to strive to maintain a good relationship with both parties, but in a world without peace this was not an easy task.

As the table of contents indicates, the majority of the text is about the Bucharest pages. I believe that there is an abundance of information on the functioning of both the Bucharest and the Eszék (in Croatian: Osijek) newspapers that is new to us. For me, the eighth chapter, the one on the Slavonian Hungarian Newspaper, was the most interesting as I could read about a press product I had not heard of before.

According to István Apró, 'The volume, like all research documentation, was able to present only part of the complex, in many ways almost chaotic world from which our no simpler present is derived. This part, on the other hand, is well documented and well developed; so, it can provide a solid basis for further research. ${ }^{12}$ I believe that the book is strongly characterized by its sophistication, its scientific consolidation, and its thoroughness, while its comprehensible language increases the reader's interest in this subject. The book manages to convey information in a way that keeps the reader's attention constantly engaged.

9 W. cit., p. 203-209.

10 W. cit., p. 189. In Hungarian: „A kivándorolt magyarságnak a szomszédos román és horvát (szerb) nyelvterületen megjelent lapjai barátságtalan, sőt ellenséges politikai közegben fejtették ki múködésüket.”

11 Ibidem.

12 W. cit., p. 209. In Hungarian: „A kötet, mint minden kutatási dokumentáció, csak egy részét tudta bemutatni annak az összetett, sok tekintetben már-már kaotikus világnak, amiből semmivel sem egyszerúbb jelenünk származik. Ez a rész viszont jól dokumentált és kellően kidolgozott, tehát a további kutatások számára szilárd alapul szolgálhat.” 